\title{
Stages of change and factors associated with misperceived eating behavior in obese individuals
}

\author{
Estágios de mudança e fatores associados à \\ percepção equivocada do comportamento \\ alimentar em obesos
}

Lydiane Bragunci BEDESCHI ${ }^{1}$

Aline Cristine Souza LOPES ${ }^{1}$

Luana Caroline dos SANTOS ${ }^{1}$

\section{A B S T R A C T}

\section{Objective}

To evaluate the stages of behavior change related to fat and fruit/vegetable intakes and the factors associated with misperceived eating behavior (pseudo-maintenance).

\section{Methods}

This cross-sectional study collected sociodemographic, socioeconomic, health, and food intake data from obese individuals ( $n=103$ ) aged $\geq 20$ years. Stages of behavior change according to the Transtheoretical Model were measured for fat and fruit/vegetable intakes. The pseudo-maintenance stage was reclassified in subjects in the action/maintenance stage who had inappropriate food habits. Multiple logistic regression models were proposed to assess the factors associated with misperceptions.

\section{Results}

The prevalences of pseudo-maintenance for fat and fruit/vegetable intakes were 23.3 and $19.4 \%$, respectively. The factors associated with misperceived fat intake were overconsumption of saturated fatty acids $(\mathrm{OR}=3.84$; 1.18-12.56) and age (OR=1.06; 1.02-1.11), and with fruit and vegetable intake, income (OR=0.99; 0.98-0.99).

\footnotetext{
1 Universidade Federal de Minas Gerais, Escola de Enfermagem, Departamento de Nutrição. Av. Prof. Alfredo Balena, 190, $3^{\circ}$ Andar, Sala 324, Santa Efigênia, 30130-100, Belo Horizonte, MG, Brasil. Correspondência para/Correspondence to: LC SANTOS. E-mail: <luanacstos@gmail.com>.

Article based on the master's thesis of LB BEDESCHI, intitled "Interface entre consumo e comportamento alimentar, inflamação e os fatores de risco cardiovascular entre indivíduos com excesso de peso". Universidade Federal de Minas Gerais; 2014.

Support: Conselho Nacional de Desenvolvimento Científico e Tecnológico (Process no 473496/2010-0) and Pró-Reitora de Pesquisa of Universidade Federal de Minas Gerais.
} 


\section{Conclusion}

The results reveal that perceived eating behavior and actual food intake diverge from anthropometric and health data, signaling the need of different intervention strategies to raise awareness in this group for the need of modifications.

Keywords: Diet, fat-restricted. Eating behavior. Fruit. Obesity. Vegetable.

\section{RE S U M O}

\section{Objetivo}

Avaliar os estágios de mudanças de comportamento relacionadas ao consumo de gordura e frutas/hortaliças e os fatores associados à percepção equivocada do comportamento alimentar (pseudomanutenção).

\section{Métodos}

Estudo transversal com indivíduos obesos ( $n=103$ ) com idade $\geq 20$ anos. Dados sociodemográficos, econômicos, de saúde e de ingestão de alimentos foram obtidos. Os estágios de mudanças de comportamento foram aferidos segundo o Modelo Transteórico para o consumo de gordura e frutas/hortaliças. A reclassificação no estágio de pseudomanutenção foi realizada nos indivíduos em fase de ação/manutenção que apresentaram inadequações no consumo alimentar. Modelos de regressão logística foram propostos para avaliar os fatores associados às percepções equivocadas.

\section{Resultados}

As prevalências de pseudomanutenção para o consumo de gordura e frutas/hortaliças foram de 23,3 e 19,4\%, respectivamente, e os fatores associados à percepção equivocada do teor de gordura na dieta foram o consumo excessivo de ácidos graxos saturados $(O R=3,84 ; 1,18-12,56)$ e idade $(O R=1,06 ; 1,02-1,11)$, enquanto para 0 consumo de frutas/hortaliças o fator foi a renda (OR=0,99; 0,98-0,99).

\section{Conclusão}

Os resultados revelam uma discordância entre a percepção do comportamento alimentar e os hábitos reais de consumo alimentar, perfil antropométrico e de saúde, sinalizando a necessidade de estratégias diferenciadas de intervenção a fim de despertar a consciência desses obesos para a necessidade de modificações.

Palavras-chave: Dieta com restrição de gorduras. Comportamento alimentar. Frutas. Obesidade. Verduras.

\section{INTRODUCTION}

The obesity epidemic represents one of the biggest global public health challenges. The World Health Organization ${ }^{1}$ indicates that 36 million deaths (60\% of all causes) occur annually due to chronic noncommunicable diseases associated with overweight, and $80 \%$ of these deaths occur in middle- and low-income countries².

Oliveira et al. ${ }^{3}$ revealed that the direct costs attributable to obesity in 2011 for the Unified Health System in Brazil approached $\mathrm{R} \$ 490$ million. It is also estimated that approximately $\$ 280$ million per year ${ }^{4}$ could be spared by the Brazilian government if the population adopted a healthier diet and lifestyle. In the same vein, several authors ${ }^{5,6}$ suggest that dietary and lifestyle changes are more effective than drug therapy for treating obesity.

In this sense, it is important to highlight dietary intake assessment since low intake of total fat, especially saturated and trans fatty acids, and high intake of fruits, vegetables, and whole grains are the strategies of choice for balancing calorie intake over time, consequently achieving a healthy weight ${ }^{5-7}$.

However, the management of obesity carries challenges due to its multifactorial nature, revealing the need for assessments that go beyond food intake. Accordingly, behavioral theoretical models have emerged, in particular the Transtheoretical Model ${ }^{8}$, which has been frequently used in studies ${ }^{9-12}$ that reduced health risk behaviors. 
One of the pillars of the Transtheoretical Model is the evaluation of the stages of change, that part of an individual's perception that builds possibilities of changing their behavior according to their readiness. However, it is commonly observed that people, especially the overweight, have a distorted view of their food intake ${ }^{13}$, which presents one of the biggest obstacles to behavioral change. This misperception can be directly influenced by the subjects' environment: low levels of education and income and high exposure to stressful activities or socialization contribute to an optimistic assessment of dietary behavior $^{14}$.

To solve potential controversies between self-assessment and actual intake, Steptoe et al. ${ }^{15}$ suggested a reclassification of individuals with the parallel implementation of tools that quantitatively assess food intake. A pseudo-maintenance stage, which includes individuals who are classified in the advanced stages of readiness to change behavior but do not have appropriate food habits, is therefore proposed. This strategy enables better identification and grouping of people with similar characteristics, providing opportunities for more effective intervention actions.

Accordingly, this article intended to evaluate if socioeconomic, health, and dietary variables are related to the stages of change of the Transtheoretical Model for some of the key behaviors for weight control, such as fat, fruit, and vegetable intakes by obese individuals. Moreover, as the recent literature has highlighted, the study also tested whether such factors are associated with a distorted perception of eating behavior.

\section{METHODS}

This study was approved by the local Research Ethics Committee under Protocol $n^{\circ}$ 0339.0.203.000.09 ETIC. This was a crosssectional study of users of a Primary Health Care service of the Sistema Único de Saúde (Brazilian
Unified Health Care System) located in a metropolis in the state of Minas Gerais, Brazil. Previous studies $^{16,17}$ revealed a high prevalence of obesity and related diseases in this setting, leading to this study.

The sample consisted of all obese service users aged $\geq 20$ years (Body Mass Index [BMI] $\geq 30 \mathrm{~kg} / \mathrm{m}^{2}$ ) who agreed to participate ${ }^{18}$. The selection ( $n=103$ ) occurred by brief interviews between February and March 2012, during which time anthropometric measurements (weight, height, and waist and hip circumferences) and health information were collected. Those with a history of mental health problems $(n=2)$ or who were pregnant $(n=1)$ were excluded from the study. The number of individuals selected for this study represents approximately $35 \%$ of the sample universe $(\mathrm{N}=300)$ of the Primary Health Care service in question.

After providing written informed consent, the participants underwent a thorough nutritional history collection that was previously coded and tested and adapted to this study ${ }^{19}$. Sociodemographic and socioeconomic data were collected, and food intake and behavior (stages of change according to the Transtheoretical Model) were assessed.

Age, family income, number of household members, and education level were also collected. The per capita income was calculated by dividing household income by the number of residents. Additionally, previous diagnoses, chronic use of medication, and conditions such as diabetes, hypertension, dyslipidemia, and heart disease were investigated.

Dietary intake was assessed by administrating two 24-hour dietary recalls on nonconsecutive days and by investigating the number of fruit and vegetable servings and frequency (daily, weekly, monthly, rarely, or never) consumed in the previous 6 months. These data were collected during two meetings.

Nutrient intake was calculated from the mean intake of two 24-hour recalls by the software DietWin Professional $2.0^{\circledR}$ (Porto Alegre, 
Rio Grande do Sul, Brazil). Calorie intake was compared to the recommended intake by the Estimated Energy Requirement formula of the Institute of Medicine ${ }^{20}$ for overweight individuals, considering a level of physical activity of 1.12 for men and 1.16 for women. Energy intake was deemed appropriate when the average number of calories in both 24-hour recalls was between minus two standard deviations and plus two standard deviations of the estimated energy requirement (minimum and maximum individual variability, respectively). The distribution of macronutrients (carbohydrates, proteins, total lipids, saturated fatty acids, monounsaturated fatty acids, and polyunsaturated fatty acids) and cholesterol was evaluated according to the ranges proposed by the Brazilian Cardiology Society ${ }^{21}$ specific for sex, age, and nutritional status. Fruit and vegetable intake was expressed as the number of servings and frequency.

Each participant's dietary behaviors were investigated through the Transtheoretical Model stages of behavior change using the questionnaire proposed by Sutton et al. ${ }^{22}$, which aims to assess participants according to four criteria/behaviors: size/quantity of servings, fat intake, fruit and vegetable intake, and level of physical activity.
However, this study only used two of the constructs included in the instrument - fat intake and fruit and vegetable intake - because they are parameters with reclassification methodologies of well-defined stages of change ${ }^{23,24}$.

Thus, as the interviewers questioned participants about their eating attitudes for each of the evaluated constructs (sample questions can be viewed in Chart 1), they classified the stages of change based on the answer.

In the pre-contemplation stage, behavior change has not been considered by the individual, i.e., no changes in behavior were made and there is no intention of making them in the near future. In the contemplation stage, the individual begins to consider behavior change but does not have concrete plans to do so. In the preparation stage, the individual has decided to change his behavior in the next month but has not yet made changes. In the action stage, individuals changed their behavior in the previous 6 months. In the maintenance stage, changes have already been made and maintained for more than 6 months $^{8}$.

Based on the identification of the stages of change, individuals were grouped into two major groups: 1) pre-action: individuals in the pre-

Chart 1. Some of questions asked to the participants regarding fat and fruit/vegetable intakes to assess the stages of change. Belo Horizonte (MG), Brazil, 2012.

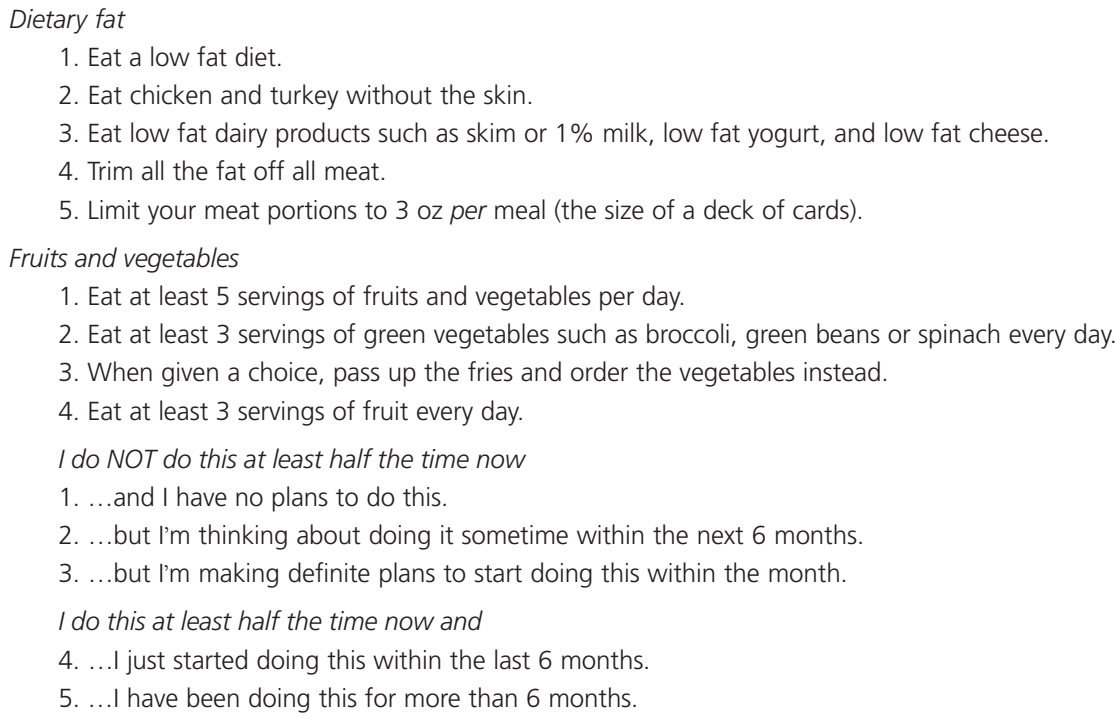


contemplation, contemplation, and preparation stages; and 2) action: individuals in the action and maintenance stages ${ }^{25}$.

After implementation of the categorization of the stages of change, quantitative dietary intake was assessed together with subsequent comparison of the classifications of the stages of change and intake itself.

To this end, a total fat intake $<35 \%$ of the total calories ${ }^{21}$ and a fruit and vegetable intake $\geq 5$ servings/day were considered appropriate ${ }^{26}$.

Thus, users who reported being in the action and maintenance stages for any of the above parameters and presented an inappropriate diet were reclassified into the pseudo-maintenance stage as suggested by Steptoe et al. ${ }^{15}$.

The database was constructed in the software Epi Info 6.04 (Atlanta, Georgia, United States), and the statistical analyses were performed by the software Statistical Package for the Social Sciences (SPSS Inc., Chicago, Illinois, United States) version 18.0 for Windows (Redmond, Washington, United States).

The descriptive analysis included the calculation of frequencies and the KolmogorovSmirnov test to determine whether the variables had normal distribution. Variables with normal distribution are expressed as mean and standard deviation, and variables without normal distribution, as medians and interquartile ranges $\left(\mathrm{P}_{25}-\mathrm{P}_{75}\right)$. The Chi-square, Fisher's exact, and McNemar tests compared proportions and analyzed the correlations between independent and dependent categories, respectively. The significance level was set at $5 \%$.

Simple logistic regression analyzed the relationships between each independent variable and the outcomes (pseudo-maintenance to reduce fat intake; pseudo-maintenance for fruit and vegetable intake), and all variables with $p \leq 0.20$ were included in the multivariate model. Subsequently, multiple logistic regression models adjusted for Primary Health Care service use duration by the participants were proposed in the Backward method. The association was estimated by the Wald statistic considering a significance level of $5 \%(p<0.05)$. All conditions necessary for model creation were observed.

\section{RES U L T S}

The 103 users had the following characteristics: predominantly women (82.5\%; $n=85)$; mean age of $54.3 \pm 14.4$ years; per capita annual income between $\$ 2,025-50,382$ USD $\left(\mathrm{P}_{25}-\mathrm{P}_{75}\right)$; and median study period of 6 (4-11) years.

Regarding the stages of change, we observed that most individuals were in the action and maintenance stages for the two behaviors (fat intake, 90.2\%, $n=93$; fruit and vegetable intake, 68.9\%, $n=71$ ) (Tables 1, 2, and 3).

The sociodemographic, anthropometric, and dietary means of the participants in the earlier stages of change (pre-action: pre-contemplation,

Table 1. Percentage of participants in the stages of change according to fat intake and fruit and vegetable intake. Belo Horizonte (MG), Brazil, 2012

\begin{tabular}{lccccc}
\hline \multirow{2}{*}{ Stages of change } & \multicolumn{3}{c}{ Fat intake } & & \multicolumn{2}{c}{ Fruit and vegetable intake } \\
\cline { 2 - 4 } \cline { 5 - 6 } & $\mathrm{n}$ & $\%$ & $\mathrm{n}$ & $\%$ \\
\hline Pre-contemplation & 1 & 1.0 & 15 & 6.8 \\
Contemplation & 5 & 4.9 & 7 & 10 & 9.7 \\
Preparation & 4 & 7.8 & 7 & 6.8 \\
Action & 8 & 82.4 & 64 & 62.1 \\
Maintenance & 84 & &
\end{tabular}

Note: $\mathrm{n}$ : Refers to the number of respondents. 
contemplation, and preparation) were compared with those of the other participants in the action and maintenance stages (low fat intake and high fruit and vegetable intake) (Tables 2 and 3). Individuals in the action and maintenance stages consumed more fruit and vegetable servings. The groups did not differ regarding the reduction of fat intake (Tables 2 and 3).
When the stages of change were reclassified, the frequency of individuals in the action and maintenance stages decreased significantly (fat intake: from 90.2 to $67.0 \%, p=0.002$; fruit and vegetable intake: 68.9 to $49.5 \%, p=0.004$ ). Pseudo-maintenance was detected in 23.3 and $19.4 \%$ of the subjects for the first and second behaviors, respectively.

Table 2. Demographic and anthropometric characteristics and diet profile according to pre-action and action stages to fat intake. Belo Horizonte (MG), Brazil, 2012.

\begin{tabular}{|c|c|c|c|c|c|}
\hline \multirow{3}{*}{ Variable } & \multicolumn{5}{|c|}{ Fat intake } \\
\hline & \multicolumn{2}{|c|}{ Pre-action (PC, C, PR) n=10 } & \multicolumn{2}{|c|}{ Action $(A, M) n=93$} & \multirow{2}{*}{$p$-value } \\
\hline & Mean & SD & Mean & SD & \\
\hline Age (years) & 43.7 & 18.7 & 56.0 & 13.5 & 0.071 \\
\hline Per capita income $(\mathrm{R} \$)$ & 675.2 & 381.4 & 588.9 & 354.2 & 0.509 \\
\hline Education level (years) & 8.6 & 2.9 & 6.9 & 4.6 & 0.115 \\
\hline Body mass index $\left(\mathrm{kg} / \mathrm{m}^{2}\right)$ & 32.0 & 1.8 & 33.1 & 3.8 & 0.158 \\
\hline Waist circumference $(\mathrm{cm})$ & 94.9 & 7.6 & 96.8 & 10.7 & 0.498 \\
\hline Percentage of body fat (\%) & 34.8 & 5.6 & 38.3 & 6.1 & 0.158 \\
\hline Energy intake (kcal) & 1506.0 & 407.4 & 1497.2 & 452.8 & 0.955 \\
\hline Carbohydrate intake (\%) & 49.5 & 8.6 & 53.0 & 8.1 & 0.296 \\
\hline Protein intake (\%) & 14.9 & 3.0 & 15.3 & 4.0 & 0.764 \\
\hline Saturated fatty acid intake (\%) & 10.1 & 2.3 & 8.6 & 2.3 & 0.099 \\
\hline Monounsaturated fatty acid intake (\%) & 9.8 & 1.9 & 8.4 & 2.5 & 0.074 \\
\hline Polyunsaturated fatty acid intake (\%) & 11.9 & 5.2 & 10.1 & 4.0 & 0.371 \\
\hline Cholesterol intake (mg) & 232.2 & 162.5 & 167.4 & 87.4 & 0.301 \\
\hline
\end{tabular}

Note: PC: Pre-Contemplation; C: Contemplation; PR: Preparation; A: Action; M: Maintenance; SD: Standard Deviation.

Table 3. Demographic and anthropometric characteristics and diet profile according to pre-action and action stages to fruit and vegetable intake. Belo Horizonte (MG), Brazil, 2012.

\begin{tabular}{|c|c|c|c|c|c|}
\hline \multirow{3}{*}{ Variable } & \multicolumn{5}{|c|}{ Fruit and vegetable intake } \\
\hline & \multicolumn{2}{|c|}{ Pre-action $(P C, C, P R) n=32$} & \multicolumn{2}{|c|}{ Action $(A, M) n=71$} & \multirow{2}{*}{$p$-value } \\
\hline & Mean & SD & Mean & SD & \\
\hline Age (years) & 53.4 & 15.8 & 55.4 & 13.8 & 0.561 \\
\hline Per capita income $(\mathrm{R} \$)$ & 686.9 & 432.8 & 432.8 & 308.8 & 0.270 \\
\hline Education level (years) & 6.6 & 4.2 & 7.3 & 4.6 & 0.616 \\
\hline Body mass index $\left(\mathrm{kg} / \mathrm{m}^{2}\right)$ & 32.0 & 3.7 & 33.5 & 3.6 & 0.064 \\
\hline Waist circumference $(\mathrm{cm})$ & 96.3 & 8.3 & 96.8 & 11.3 & 0.814 \\
\hline Percentage of body fat (\%) & 36.0 & 8.1 & 38.8 & 4.8 & 0.128 \\
\hline Energy intake (kcal) & 1495.0 & 457.5 & 1498.9 & 445.6 & 0.977 \\
\hline Carbohydrate intake (\%) & 51.2 & 10.3 & 53.5 & 6.9 & 0.211 \\
\hline Protein intake (\%) & 14.8 & 3.7 & 15.4 & 4.1 & 0.494 \\
\hline Saturated fatty acid intake (\%) & 8.7 & 2.6 & 8.7 & 2.2 & 0.941 \\
\hline Monounsaturated fatty acid intake (\%) & 9.3 & 3.4 & 8.2 & 1.8 & 0.052 \\
\hline Polyunsaturated fatty acid intake (\%) & 10.9 & 4.7 & 9.9 & 3.8 & 0.319 \\
\hline Cholesterol intake (mg) & 179.6 & 83.0 & 170.0 & 103.0 & 0.636 \\
\hline Fruit and vegetable servings/day & 3.0 & 1.8 & 5.0 & 1.8 & $<0.001$ \\
\hline
\end{tabular}

Note: PC: Pre-Contemplation; C: Contemplation; PR: Preparation; A: Action; M: Maintenance; SD: Standard Deviation. 
The variables associated with the pseudomaintenance stage in the final logistic model controlled by primary health care service use duration in relation to fat intake were excessive saturated fatty acid intake (OR=3.84; 1.18-12.56), and age $(O R=1.06 ; 1.02-1.11)$, i.e., an intake of saturated fatty acids $>10 \%$ of the caloric content of the diet and higher age increased the chance of misperceiving fat intake (Table 4).

However, regarding the behavior of fruit and vegetable intake, per capita income ( $O R=0.99 ; 0.98-0.99)$ was associated with pseudo-maintenance, indicating that lower income favors misperception of a possibly adequate fruit and vegetable intake (Table 4).

\section{DISCUSSION}

This study showed that in a population of individuals with excess weight, approximately $70 \%$ classified themselves in the action and maintenance stages for the assessed behaviors, and approximately $20 \%$ misperceived their own intake of fats, fruits, and vegetables. In addition, the mean daily intake of fruit and vegetable servings was significantly higher among participants in the action and maintenance stages, with income being the factor associated with the pseudomaintenance stage for fruit and vegetable intakes. Regarding fat intake, excessive intake of saturated fat and age were the factors associated with pseudo-maintenance.

Table 4. Factors associated with pseudo-maintenance to fat intake and fruit and vegetable intake, adjusted for primary health care service use duration (months). Belo Horizonte (MG), Brazil, 2012.

\begin{tabular}{|c|c|c|c|c|}
\hline \multirow{3}{*}{ Variables } & \multicolumn{4}{|c|}{ Univariate analysis } \\
\hline & \multicolumn{4}{|c|}{ Fat intake } \\
\hline & OR & Z & $p$-value & $95 \% \mathrm{Cl}$ \\
\hline Age (years) & 1.06 & 2.76 & 0.006 & $1.02-1.10$ \\
\hline Per capita income (U\$/y) & 1.00 & 1.78 & 0.075 & $0.99-1.00$ \\
\hline Residents per household & 0.78 & -1.54 & 0.124 & $0.59-1.07$ \\
\hline Education level (years) & 0.93 & -1.42 & 0.157 & $0.83-1.03$ \\
\hline Diabetes Mellitus type ॥ & 1.97 & 1.31 & 0.189 & $0.71-5.41$ \\
\hline Excessive saturated fatty acid intake (\%) & 6.44 & 3.64 & $<0.001$ & $2.36-17.56$ \\
\hline \multirow[t]{3}{*}{ Excessive monounsaturated fatty acid intake (\%) } & 7.89 & 3.91 & $<0.001$ & $2.81-22.20$ \\
\hline & \multicolumn{4}{|c|}{ Fruit and vegetable intake } \\
\hline & OR & Z & $p$-value & $95 \% \mathrm{Cl}$ \\
\hline Per capita income (U\$/y) & 0.99 & -2.5 & 0.012 & 0.98-0.99 \\
\hline Hypercholesterolemia & 2.90 & 2.05 & 0.041 & $1.05-8.05$ \\
\hline \multirow[t]{4}{*}{ Excessive polyunsaturated fatty acid intake (\%) } & 4.55 & 1.38 & 0.166 & $0.53-38.80$ \\
\hline & \multicolumn{4}{|c|}{ Multivariate Analysis } \\
\hline & \multicolumn{4}{|c|}{ Fat intake } \\
\hline & OR & Z & $p$-value & $95 \% \mathrm{Cl}$ \\
\hline Age (years) & 1,06 & 2,58 & 0,010 & $1,02-1,11$ \\
\hline \multirow[t]{3}{*}{ Excessive saturated fatty acid intake (\%) } & 3,84 & 2,23 & 0,026 & $1,18-12,56$ \\
\hline & \multicolumn{4}{|c|}{ Fruit and vegetable intake } \\
\hline & OR & z & $p$-value & $95 \% \mathrm{Cl}$ \\
\hline Per capita income (U\$/y) & 0,99 & $-2,49$ & 0,013 & $0,98-0,99$ \\
\hline
\end{tabular}

Note: Determination coefficient (Pseudo $R^{2}$ ) for fat intake=0.260; determination coefficient (Pseudo $R^{2}$ ) for fruit and vegetable intake=0.084. OR: Odds Ratio; $95 \% \mathrm{Cl}$ : 95\% Confidence Interval. 
This study has some limitations. First, a potential confounder is the use of self-reported data, which may be influenced by participant cognition, idiom, and education. Reporting reliability, especially regarding behavioral assessment, may have been influenced by social acceptance desirability, which was defined by Ballard et al. ${ }^{27}$ as the propensity of an individual to provide the answer he considers most desired and accepted by society regardless of its accuracy.

The original instrument was designed to be self-administered, so the use of an interviewer for collecting information may have influenced the results, both in relation to the factor of social acceptance desirability and impression management, which is the process through which people behave in particular ways to create a desired social image in an attempt to control the impressions that others have of them regarding behaviors, motivations, morality, and personal attributes ${ }^{28}$. However, it should be emphasized that, to mitigate these types of biases, the study interviewers were trained not to show favorable reactions to ideas of judgment during the individual interviews.

Some hypotheses have been proposed for the high proportion of action and maintenance behaviors related to fat and fruit/vegetable intakes. The first rests again on the issue of impression management and social desirability. Obese individuals need to be accepted and not reprimanded for their behavior, especially by health professionals, who generally do not tend to host their aches and pains. Lack of empathy and responsiveness by health professionals leads to the omission of eating behavior questions in obese people. This situation greatly hinders the identification of the actual stage of change for future interventions in these patients. The second hypothesis stems from a possible misperception of their own intake ${ }^{13,28}$, a disturbing trend of optimistic self-evaluation of eating behavior.

Misperceived fat intake can result from the difficulty of estimating food intake and nutritional content, particularly saturated fatty acid content ${ }^{13}$.
The estimation of fat intake may also be influenced by cognitive issues, and the participants' low level of education may hinder the understanding of food labels ${ }^{14}$. Additionally, individuals tend to overestimate small improvements in their routine, such as the purchase of low-fat foods, considering them global behavior changes, although no significant and consistent changes were actually implemented ${ }^{13}$.

In this sense, the severity of excessive saturated fatty acid intake is associated with pseudo-maintenance of fat intake behavior since this information indicates that individuals with a higher intake of saturated fatty acids believe they have reduced fat intake when actually they have not. This aspect becomes even more important because obesity significantly increases cardiovascular risk ${ }^{4}$.

Although the Brazilian food intake survey ${ }^{29}$ indicated that eating habits tend to improve with age (such as higher consumption of fruits and vegetables, for example), this study found an association between higher age and higher misperception of fat intake. Higher age is also associated with a natural increase in the resistance to change behavioral patterns and to assimilate new knowledge, which could explain this discrepancy between actual intake and perceived eating behavior.

Regarding fruit and vegetable intake, $\mathrm{Di}$ Noia \& Thompson ${ }^{25}$ also observed high resistance to this everyday behavior. Despite already knowing about the importance of incorporating this dietary practice for weight control, subjects do not necessarily put it into practice for various reasons, such as financial limitations, lack of motivation or willpower, and lack of social support ${ }^{25,30}$.

Income is considered one of the major determinants of food choices and access, exerting great influence on perceived and reported intake $^{14}$. A Brazilian population-based survey found higher fruit and vegetable intake by higher income brackets parallel to the prioritization of foods high in refined carbohydrates by lower 
income classes ${ }^{29}$. Furthermore, limited access to foods of better nutritional quality is one of the causes of obesity ${ }^{31}$.

Dietary advice in obesity is a challenging task due to the difficulties obese subjects have to sustain long-term changes, coupled with emotional factors and a history of repeated failed weight loss attempts ${ }^{32}$. The nutritional management of these participants, especially those in the pseudomaintenance stage, requires extreme skill. They recognize risky behavior but do not identify themselves as practitioners of such conduct, which makes addressing the need of change even more complex and critical.

Accordingly, the great potential of this study is the differentiation between intake and eating behavior assessments. Behavioral assessments help to widen our understanding of the mechanisms of dietary change ${ }^{12}$. In addition to enhancing their knowledge about healthy eating, people need to recognize their eating habits, confront their health conditions, and be effectively convinced that the changes in their habits will promote positive results that will significantly impact their quality of life.

Bearing in mind the global scenario, in which the rates of obesity and cardiovascular events increase as the quality of dietary patterns worsen, our findings also indicate a significant demand for incentives to promote healthy eating habits as they relate to appropriate intakes of fats, sugars, fruits, and vegetables, which aim to control weight and promote health.

The results of this study also show the need for differentiated approaches according to the characteristics of the individuals involved, taking into account factors such as age and income, in addition to nutrient intake. Moreover, specialized nutritional interventions are a priority in individuals in the pseudo-maintenance stage, highlighting the importance of behavioral assessment to better structure the management of individuals with excess weight.

\section{ACKNOWLEDGEMENTS}

The translation of this manuscript into English language had financial aid from Pró-Reitoria de Pesquisas of Universidade Federal de Minas Gerais.

\section{CONTRIBUTORS}

LB BEDESCHI contributed to the study design, data analysis, results interpretation, and article writing. ACS LOPES and LC SANTOS contributed to the study design, fundraising, and final review.

\section{RE FER E N C E S}

1. World Health Organization. Global status report on noncommunicable diseases. Geneva: WHO; 2010 [cited 2013 Jan 6]. Available from: http:// whqlibdoc. who.int/publications/2011/978924 0686458_eng.pdf

2. Organización Pan-Americana de la Salud. Melhoria dos cuidados crônicos por meio das redes de atenção primária à saúde. Washington (DC): OPAS; 2012.

3. Oliveira ML, Santos LMP, Silva EN. Bases metodológicas para estudos de custos da doença no Brasil. Rev Nutr. 2014; 27(5):585-95. http://dx. doi.org/10.1590/1415-52732014000500007

4. Bahia L, Coutinho ES, Barufaldi LA, Abreu GA, Malhão TA, de Souza $C P$, et al. The costs of overweight and obesity-related diseases in the Brazilian public health system: Cross-sectional study. BMC Public Health. 2012; 12(1):440-56.

5. Ross R, Després JP. Abdominal obesity, insulin resistance, and the metabolic syndrome: Contribution of physical activity/exercise. Obesity. 2009; 17(Suppl. 3):S1-2.

6. Tierney AC, McMonagle J, Shaw DI, Gulseth $\mathrm{HL}$, Helal O, Saris WH, et al. Effects of dietary fat modification on insulin sensitivity and on other risk factors of the metabolic syndrome FLIPGENE: A European randomized dietary intervention study. Int J Obesity. 2011; 35(6):800-9.

7. Healthy People. Nutrition and weight status. Washington (DC): U.S. Department of Health and Services; 2012 [cited 2013 Dec 7]. http://www. healthypeople.gov/2020/topicsobjectives2020/ ebr.aspx?topicld $=29$

8. Prochaska JO, Velicer WF. The transtheoretical model of health behavior change. Am J Health Promot. 1997; 12(1):38-48. 
9. Prochaska JO, Velicer WF, Rossi JS, Redding CA, Greene GW, Rossi SR, et al. Multiple risk expert systems interventions: Impact of simultaneous stage-matched expert system interventions for smoking, high-fat diet, and sun exposure in a population of parents. Health Psychol. 2004; 23(5):503-16.

10. Prochaska JO, Velicer WF, Redding C, Rossi JS, Goldstein M, DePue J, et al. Stage-based expert systems to guide a population of primary care patients to quit smoking, eat healthier, prevent skin cancer, and receive regular mammograms. Prev Med. 2005; 41(2):406-16.

11. Velicer WF, Prochaska JO, Redding CA, Rossi JS, Sun X, Rossi SR, et al. Efficacy of expert system interventions for employees to decrease smoking, dietary fat, and sun exposure. Int J Behav Med. 2004; 11(S1):277.

12. Greene GW, Redding CA, Prochaska JO, Paiva AL, Rossi JS, Velicer WF, et al. Baseline transtheoretical and dietary behavioral predictors of dietary fat moderation over 12 and 24 months. Eat Behav. 2013; 14(1):255-62.

13. Plotnikoff RC, Hotz SB, Johnson ST, Hansen JS, Birkett NJ, Leonard LE, et al. Readiness to shop for low-fat foods: A population study. J Am Diet Assoc. 2012; 109(8):1392-7.

14. Toral N, Slater B. Transtheoretical model approach in eating behavior. Ciênc Saúde Colet. 2007; 12(6):1641-50.

15. Steptoe A, Wijetunge S, Doherty S, Wardle J. Stages of change for dietary fat reduction: Associations with food intake, decisional balance and motives for food choice. Health Edu J. 1996; 55:108-22.

16. Costa BVL, Mendonça RD, Santos LC, Peixoto SV, Alves M, Lopes ACS. Academia da Cidade: um serviço de promoção da saúde na rede assistencial do Sistema Único de Saúde. Ciênc Saúde Colet. 2013; 18(1):95-102.

17. Moreira RAM, Santos LC, Lopes ACS. A qualidade da dieta de usuários de Serviço de Promoção de Saúde difere do comportamento alimentar obtido pelo modelo transteórico. Rev Nutr. 2012; 25(6):719-30. http://dx.doi.org/10.1590/\$1415-5 2732012000600004

18. World Health Organization. Physical status: The use and interpretation of anthropometry. Technical Report Series, nº 854. Geneva: WHO; 1995.

19. Lopes ACS, Ferreira AD, Santos LC. Atendimento nutricional na atenção primária à saúde: proposição de protocolos. Nutr Pauta. 2010; 101:40-4.

20. Institute of Medicine. Dietary Reference Intakes: The essential guide to nutrient requirements. Washington (DC): IOM; 2006.
21. Sociedade Brasileira de Cardiologia. I Diretriz brasileira de diagnóstico e tratamento da síndrome metabólica. Arq Bras Cardiol. 2005; 84(Supl. 1):1-27.

22. Sutton K, Logue E, Jarjoura D, Baughman K, Smucke W, Capers C. Assessing dietary and exercise stage of change to optimize weight loss interventions. Obes Res. 2003; 11(5):641-52.

23. Greene GW, Rossi SR. Stages of change reducing dietary fat intake over 18 months. J Am Diet Assoc. 1998; 18(5):535-6.

24. Kristal AR, Glanz K, Curry SJ, Patterson RE. How can stages of change be best used in dietary interventions? J Am Diet Assoc. 1999; 99(6):679-84.

25. Di Noia J, Thompson D. Processes of change for increasing fruit and vegetable consumption among economically disadvantaged African American adolescents. Eat Behav. 2012; 13(1):58-61. http://dx. doi.org/10.1016/j.eatbeh.2011.10.001

26. World Health Organization. Fruit and vegetable promotion initiative: A meeting report. Geneva: WHO; 2003 [cited 2013 Aug 6]. Available from: http:// www.who.int/dietphysicalactivity/publications/f\&v_ promotion_initiative_report.pdf

27. Ballard B, Crino MD, Rubenfeld S. Social desirability response bias and the Marlowe-Crowne Social Desirability Scale. Psychol Rep. 1988; 63(1):227-37.

28. Mendonça JR, Amantino-de-Andrade J. Gerenciamento de impressões: em busca da legitimidade organizacional. Rev Adm Empres. 2003; 43(1):36-48. http://dx.doi.org/10.1590/S0034-75902003000 100005

29. Instituto Brasileiro de Geografia e Estatística. Pesquisa de Orçamentos Familiares - POF 2008-2009: análise do consumo alimentar pessoal no Brasil. Rio de Janeiro: IBGE; 2011.

30. Logue EE, Jarjoura DG, Sutton KS, Smucker WD, Baughman KR, Capers CF. Longitudinal relationship between elapsed time in the action stages of change and weight loss. Obes Res. 2004; 12(9):1499-508.

31. Monteiro CA, Levy RB, Claro RM, de Castro IR, Cannon $\mathrm{G}$. Increasing consumption of ultra-processed foods and likely impact on human health: Evidence from Brazil. Public Health Nutr. 2010; 14(1):5-13.

32. Bueno JM, Leal FS, Saquy LPL, Santos CB, Ribeiro RPS. Educação alimentar na obesidade: adesão e resultados antropométricos. Rev Nutr. 2011; 24(4):575-84. http://dx.doi.org/10.1590/\$1415-52 732011000400006

Received: February 12, 2015

Final version: September 15, 2015

Approved: September 29, 2015 